\title{
Comment on: "Determining expected research skills of medical students on graduation: a systematic review"
}

\section{Ivan Sisa ${ }^{1}$}

Accepted: 22 December 2020 / Published online: 7 January 2021

(C) International Association of Medical Science Educators 2021

\section{Dear Editor,}

I am writing regarding the systematic review published by Lee MGY and colleagues entitled "Determining expected research skills of medical students on graduation: a systematic review" [1]. Although the authors used two well-known databases (MEDLINE and ERIC) to retrieve articles related to medical student research programs, the potential to have omitted relevant publications cannot be ruled out, as the authors stated in the limitations section of their publication. In fact, a relevant publication covering this important topic has been omitted, published in 2016 in Medical Science Educator [2], which would have provided evidence from the faculty/supervisors' point of view combined with quantitative metrics and embedded in a mixed-methods approach. Unlike the studies listed in Table 3 under "Faculty-reported" label which represented $7.3 \%$ (3/41) of the final study sample analyzed [3-5], Solano de la Sala and colleagues reported outcome data regarding seven research core competencies (project understanding, technical skills, attention to details, analytical ability, critical ability, communication, and professionalism) and required to carry out a project from study design to dissemination of results and not only the perception of the benefits/ drawbacks of a research program or experience [2]. Thus, to evaluate these core competencies, the authors used a wellvalidated form designed by the Kansas City University of Medicine and Biosciences, which was applied in a South American Medical School, in which research curriculum was arranged with mandatory coursework and project-based program (Thesis). It would have been useful if Dr. Lee and colleagues had added to their research strategy other databases such as Scopus and Google Scholar. For instance, it is reported that Scopus covers even more journals than Web of

Ivan Sisa

isisa@usfq.edu.ec

1 School of Medicine, College of Health Sciences, Universidad San Francisco de Quito USFQ, Quito, Ecuador
Science and PubMed [6]. In doing that, the potential of evidence selection bias from missed studies would have been avoided or at least decreased substantially [7] and ultimately would have provided more robust results.

\section{Compliance with Ethical Standards}

Conflict of Interest The author declares that there are no conflicts of interest.

Ethical Approval NA

Informed Consent NA

\section{References}

1. Lee MGY, Hu WCY, Bilszta JLC. Determining expected research skills of medical students on graduation: a systematic review. Med Sci Educ. 2020;20:1465-79.

2. Solano de la Sala C, Adkison LR, Endara P, Sisa I. A 3-year retrospective assessment of student research competencies: a mixed methods study of medical school graduates in Ecuador. Med Sci Educ. 2016;26:239-46.

3. Devi V, Ramnarayan K, Abraham RR, Pallath V, Kamath A, Kodidela S. Short-term outcomes of a program developed to inculcate research essentials in undergraduate medical students. J Postgrad Med. 2015;61(3):163-8.

4. Shaikh W, Patel M, Shah H, Singh S. ABC of research: experience of Indian medical undergraduates. Med Educ. 2015;49(5):523-4.

5. Crabtree EA, Brennan E, Davis A, Squires JE. Connecting education to quality: engaging medical students in the development of evidence-based clinical decision support tools. Acad Med. 2017;92(1):83-6.

6. AlRyalat SAS, Malkawi LW, Momani SM. Comparing bibliometric analysis using PubMed, Scopus, and Web of Science databases. J Vis Exp. 2019;152. https://doi.org/10.3791/58494.

7. Drucker AM, Fleming P, Chan AW. Research techniques made simple: assessing risk of bias in systematic reviews. J Invest Dermatol. 2016;136(11):e109-14.

Publisher's Note Springer Nature remains neutral with regard to jurisdictional claims in published maps and institutional affiliations. 